\title{
Russinet i mindfulness: Erfarenhetsbaserad utbildning och praktik i religionsvetenskap
}

\author{
Daniel Enstedt \\ Göteborgs universitet, Sverige
}

I den här artikeln argumenterar jag för praktikbaserade inslag i icke-konfessionell utbildning i religionsvetenskap. Det görs utifrån några konkreta exempel på religiös praktik som jag har utarbetat inom ramen för den undervisning som jag bedriver. Förslaget gäller inte övningar i varje situation eller sammanhang, och det indikerar inte heller att religiös praktik är det enda sättet att uppnå målen med religionsvetenskaplig utbildning. Det finns även etiska implikationer av att införa religiös praktik i en icke-konfessionell utbildning som jag menar bör tas i beaktande.

Jag argumenterar för att religiös praktik kan vara ett sätt att åstadkomma ett djupinriktat lärande och tillägna sig kunskap om religion som skiljer sig från andra typer av färdighetsträning som övas inom ramen för en icke-konfessionell utbildning. Religiös praktik i utbildningen kan även, menar jag, vara ett sätt att hantera de problem som det så kallade världsreligionsparadigmet är förknippat med, som har dominerat religionsvetenskaplig utbildning, läromedelsproduktion och kursplaner. Dessa problem handlar om försanttaganden, föreställningar och definitioner som präglar paradigmets religionsförståelse.

Nyckelord: Religionsutbildning, världsreligionsparadigmet, sekularism, praktikbaserad utbildning, levd religion

\section{INLEDNING}

Praxisorienterade utbildningar, som bland annat ges för musiker, läkare och slöjdlärare, inbegriper så kallade autentiska läraktiviteter på regelbunden basis. En blivande musiker lyssnar inte bara på musik inom ramen för utbildningen utan utövar även musik. Liknande inslag finns även inom andra utbildningar som inte på samma sätt har till syfte att professionsutbilda studenter. Inom teatervetenskap - som inte syftar till att utbilda vare sig skådespelare eller regissörer - kan studenternas egen uppsättning av en teaterföreställning vara avgörande för att få kunskap om teaterns komponenter, formspråk och villkor. Sådana erfarenhetsbaserade eller praxisorienterade inslag förekommer inom en rad olika utbildningar med olika syften (se Herrington \& Herrington, 2005; Burke, 2009, s. 5). På samma vis kan en konfessionell teologisk utbildning inbegripa religiös praktik. Icke-konfessionell religionsutbildning innehåller vanligtvis inte sådana element som fokuserar på att praktisera religion (Walvoord, 2008). Däremot kan utbildningen naturligtvis innehålla praktiska övningar där studenten övar sin analytiska förmåga eller generiska kompetenser som att formulera sig i skrift och tal. Men en religionsvetenskaplig utbildning, som inför religiös praktik som en del av utbildningen, lyser som sagt vanligtvis med sin frånvaro i icke-konfessionella studier av religion.

*Författarkontakt: daniel.enstedt@lir.gu.se

Artiklar och reflektioner är kollegialt granskade. Övriga bidragstyper granskas av redaktionen. Se https://hogreutbildning.se ISSN 2000-7558

(C)2020 Daniel Enstedt. This is an Open Access article distributed under the terms of the Creative Commons Attribution-NonCommercial 4.0 International License (https://creativecommons.org/licenses/by-nc/4.0/), allowing third parties to share their work (copy, distribute, transmit) and to adapt it, under the condition that the authors are given credit, that the work is not used for commercial purposes, and that in the event of reuse or distribution, the terms of this license are made clear.

Citation: Enstedt, D. (2020). «Russinet i mindfulness: Erfarenhetsbaserad utbildning och praktik i religionsvetenskap», Högre utbildning, 10(1), 63-75. https://doi.org/10.23865/hu.v10.2118 


\section{Daniel Enstedt}

Det finns förvisso goda skäl till att universitetsutbildningen är utformad som den är. Det handlar bland annat om att undervisningen inte ska vara färgad av ett visst religiöst perspektiv, vilket är ett av resultaten av avkristnandet av den svenska skolan och utbildningen till förmån för en icke-konfessionell utbildning (Kittelmann Flensner, 20I5, s. 40-43). Poängen här är inte att argumentera för återinförandet av den tidigare ordningen, eller att utbildningen ska handla om att forma rättrogna subjekt, utan snarare att pröva tanken om praktikorienterade inslag skulle kunna ha en viktig plats även i icke-konfessionell religionsutbildning. Det finns kort sagt en risk att potentiellt stimulerande praktik- och inlevelsebaserade läraktiviteter utesluts i den icke-konfessionella religionsutbildningen.

Mot bakgrund av en sådan problematik ska jag här resonera kring olika undervisningsformer inom religionsvetenskap i relation till de ramar som sätts för icke-konfessionell utbildning i religionsvetenskap. Fokus kommer i första hand att hamna på de didaktiska frågorna snarare än de religionsvetenskapliga, och min ansats är konstruktiv och prövande snarare än deskriptiv. Det innebär att de resonemang som förs här varken baseras på en empirisk undersökning av undervisningspraktiker eller av hur yrkesverksamma lärare förhåller sig till aktuella styrdokument. Det rör sig snarare om en explorativ diskussion om hur undervisning kan bedrivas inom ramarna för icke-konfessionell utbildning om religion. Mer specifikt ska jag, inom ramen för denna avgränsade undersökning, diskutera materialitet och praxisbetonad religionsutbildning och dess betydelse för en mer generisk förståelse av religion. Med den materiella vändningen inom religionsvetenskap har fokus vänts från religion som tro, text och tanke till religionens materiella förutsättningar och uttryck. En sådan utgångspunkt innebär att "religion inte [kan] existera utan de materiella ting som gör den närvarande och synlig, och som ligger till grund för hur religionens tankevärldar och känsloliv formas" (Enstedt \& Plank, 20I8, s. I4). Mat, kläder, byggnader, hår, statyetter, figuriner och kroppar ges därigenom en förnyad uppmärksamhet och plats inom det religionsvetenskapliga studiet (Houtman \& Meyer, 20I2). De utbildningsmässiga implikationerna av en sådan materiell vändning diskuteras i det följande utifrån några konkreta exempel som jag själv har provat inom ramen för den undervisning som jag bedriver.

\section{RUSSINET I MINDFULNESS}

Jag har vid några tillfällen gett en föreläsning om mat och religion på Institutionen för kostoch idrottsvetenskap, Göteborgs universitet. Min uppgift var att ge studenterna grundläggande kunskaper om synen på mat inom några vanligt förekommande religioner. I synnerhet efterfrågades kunskaper om halal, med anledning av den ökade immigrationen från länder där islam är majoritetsreligionen. När det gäller kristendom, judendom och islam föreläste jag om olika uppfattningar och praktiker som rör mat, med förankring i religionernas urkunder och traditioner. Studenterna fick dessutom resonera om etiska dilemman som olika slaktmetoder kan vara behäftade med.

Ett grundläggande pedagogiskt problem handlar om hur det som regel teoretiska, text- och lärobaserade stoffet inte bara ska förmedlas utan också göras relevant för studenterna. Det handlar därmed om hur jag som lärare kan skapa en stimulerande lärandemiljö som gynnar ett djupinriktat lärande, men också om de specifika läraktiviteter som är bäst lämpade för detta ändamål (Pettersen, 2008, s. I27-I30; Herrington, Reeves \& Oliver, 20I4). Motivation är en central komponent när det gäller inlärning och studenters kunskapsinhämtande, i synnerhet när det gäller djupinlärning, det som Benjamin Bloom talar om som en högre nivå av lärande (Herrington \& Herrington, 2005; Airasian, Anderson, Krathwohl \& Bloom, 200I). De studenter som jag möter under denna föreläsning har vanligtvis mycket begränsade kunskaper om 
religion och det är heller inte religion som är deras intresse, utan mat. Även om studenterna inte nödvändigtvis ska benämnas som religiöst illitterata, bör frågan om hur deras religiösa litteracitet - kunskap och förståelse om religion och religiositet - kan fördjupas och förädlas inom ramen för detta moment i deras utbildning (Moore, 2007).

När buddhismen skulle behandlas valde jag ett annat material än enbart kanoniserade texter eller filosofiska utläggningar av buddhismens lära. Fokus var på hur buddhismen kommer till uttryck i dagens Sverige, sett ur ett matperspektiv, och mitt exempel blev det från buddhismens sprungna fenomenet mindfulness och den praktik som förknippas med det (Hedstrom, 20I8; Plank, 20II; Plank, 20I4). Mindfulness illustreras emellanåt utifrån olika förhållningssätt till ett russin. Jag valde därför att utgå från ett russin i lärsituationen. Studenterna fick själva i uppgift att utföra mindfulnessövningen. Inom religionsvetenskapen kan det finnas en stor tveksamhet när det gäller att föra in "det religiösa" i undervisningen. Men samtidigt förekommer mindfulness, meditation och yoga inom ramen för andra skolämnen än religionskunskap i ungdomsskolan, vilket gör att trösklarna till mindfulness kan vara lägre än om jag till exempel hade valt en kristen bön (se Enstedt, 20I4).

Jag valde ett mer populärt uttryck för mindfulness som jag hämtade ur tidskriften $M a ̊ B r a .{ }^{1}$ Efter att ha delat ut russin till studenterna, tonade jag ner ljuset och läste upp följande:

[S]ätt dig bekvämt. Börja med att andas och känn närvaron här och nu med hela kroppen. Rikta sedan uppmärksamheten mot russinet.

Betrakta det noga. Hur ser ytan ut? Hur såg det ut innan det torkades till sin nuvarande form? Visualisera hur det såg ut som druva hängandes i klasar på en vinranka i solen.

Låt russinet närma sig munnen, dofta på det och uppmärksamma hur den skrovliga ytan känns mot läpparna och kinden.

Låt det hamna i munnen - men tugga inte! Notera istället hur det känns att ha ett russin i munnen, hur den söta smaken sprider sig trots att du inte bitit i det ännu.

När tungan och munhålan utforskat russinet klart kan du sakta börja tugga.

Känn hur sött det smakar när det fördelas av tuggorna och notera hur det känns när du sväljer det.

Avsluta övningen med att sluta ögonen och känna efter vad som hänt.

- Sandberg, 2015

Russinövningen utmärks av en låg utmaning för studenterna; det är svårt att misslyckas. Dessutom har de allra flesta studenter erfarenheter och minnen av russin vilket innebär att de har förutsättningar för att kunna bearbeta den nya kunskapen som övningen syftar till (Pettersen, 2008, s. II6). Efter övningen avslutats fick studenterna tillfälle att reflektera över de religiösa matpraktikerna kosher och halal utifrån vad de hade erfarit under mindfulnessövningen. Utifrån denna relativt enkla övning kunde vi teoretisera och påbörja en analys av skillnader och likheter

1 Jag har även använt denna övning i samband med ett resonemang kring utbildningsfilosofen Gert J. J. Biestas begrepp subjektifiering och dess betydelse för humanistisk och religionsvetenskaplig utbildning (se Enstedt, 2020; Biesta, 2014). 
mellan det i buddhismen förankrade begreppet sati och den praktik som är knuten dit och den västerländska receptionen av sati i mindfulness (Plank, 20II).

En av poängerna med ett sådant upplägg är att inkludera olika moment i undervisningen där praktiska övningar blandas med teoretiska diskussioner och perspektiv på religion. En annan poäng med övningen är att studenterna själva får erfara att religion inte enbart handlar om religiös lära och tro, utan även om olika former av praktik och förhållningssätt. Det gäller naturligtvis inte bara buddhism och mindfulness, utan även andra former av religion och andlighet. Genom russinövningen får studenterna själva ta del av ett sådant förhållningssätt. Därigenom kan de reflektera kring matpraktiker inom exempelvis judendom och islam bortom lärosatser, urkunder och trosföreställningar, utan att för den sakens skull helt avfärda dessa som irrelevanta. Det är snarare när lärosatser och trosföreställningar kroppsliggörs i en levande praktik som en annan förståelse av dem - och i förlängningen en annan förståelse av religiösa förhållningssätt till mat - kan uppnås.

\section{LEVD RELIGION I UTBILDNINGEN}

Det är i huvudsak utifrån ett levd religion-perspektiv, med fokus på materialitet och religiös praktik, som jag för in praktiska element i den icke-konfessionella religionsutbildningen (Enstedt \& Plank, 20I8; Ammerman, 20I4; Ammerman, 2007; McGuire, 2007). För att klargöra betydelsen av en sådan vändning i synen på religionsvetenskaplig utbildning vänder jag mig till Stephen E. Greggs och Lynne Scholefields distinktion mellan rapporterad, representerad och levd religion:

By reported religion, we mean traditional textbook commentaries on religious traditions, which for a long time have formed the basis of much standard lecture theatre teaching. [...] By represented religion, we mean the ways in which religious people and organisations present themselves and their traditions. [...] By living religion, we mean what people actually believe and do. This is real, particular and often messy - a far cry from safe or neat accounts contained in textbooks. (Gregg och Scholefield, 20I5, s. 7)

När det gäller inslag i utbildningen som exempelvis studiebesök i ett tempel, att ta del av en judes livsberättelse, läsa Koranen eller titta på Youtubeklipp om hinduiska pilgrimer så handlar det som regel om rapporterad eller representerad religion. Levd religion riskerar i själva verket komma till uttryck som representerad religion, och därmed inte som religiös praktik eller deltagande, utan istället som något att betrakta. Mindfulnessövningen är alltså ett exempel på vad det kan innebära att införa ett levd religion-perspektiv i utbildningen som inte hemfaller i representerad eller rapporterad religion. Poängen är här inte att argumentera mot inslag av representerad och rapporterad religion, utan istället för hur frånvarande levd religion-perspektiv tenderar att vara i utbildningen.

Genom denna form av studentaktiverande övningar kan studenterna ta del av ett sätt att förhålla sig till sin omvärld som de vanligtvis inte är närmare bekanta med och kan på så sätt få inblick i andra livsvägar än den egna, vilket också är ett av syftena med kursen om mat och religion. Om studenter ges möjlighet att relatera teoretisk och faktabaserad kunskap om exempelvis religiösa matpraktiker till sina egna erfarenheter och livsberättelser genom erfarenhetsbaserade inslag i utbildningen som möjligen vid första anblicken framstår som udda inslag i den icke-konfessionella religionsutbildningen, så kan det i bästa fall skapa en utbildning som inte bara rymmer innehållsmässiga och generiska kunskaper, utan även kunskaper om andra 
människors sätt att vara vilket i sin tur både kan utmana och vara omvälvande för såväl ämnet som studenten (Enstedt, 2020 s Desjardins, 2016, s. 133).

Russinövningen är endast ett exempel på hur den religionsvetenskapliga undervisningen kan ändra fokus från ett ensidigt fokus på texter, tro och läror till att också inkludera förhållningssätt, praktiker och erfarenheter. Det skulle också kunna handla om att praktiskt genomföra en liturgi i ett klassrum inför ett studiebesök eller i en kyrka i samband med studiebesöket eller att ägna sig åt muslimsk salah under en veckas tid. Listan över möjliga övningar kan göras lång. Frågan är hur man examinerar russinövningen och de erfarenhetsbaserade kursinslagen, i synnerhet om, som Anna Hedin riktigt påpekar helt i linje med Biggs och Tangs idé om konstruktiv länkning, tentamensfrågorna "bör vara i paritet med undervisningen och kurslitteraturen" (Hedin, 2006, s. I68; Biggs \& Tang, 1999). En annan väsentlig aspekt - och kanske invändning - rör de etiska dimensionerna av att använda religiös praktik i en icke-konfessionell utbildning. Det är inte svårt att föreställa sig religiösa praktiker som vore direkt olämpliga att föra in i klassrummet, i synnerhet i relation till syftet med religionsutbildningen. Detta är dock frågor som öppnar upp för en vidare diskussion som jag återkommer till nedan. Innan jag redogör för ytterligare en övning ska jag vända mig till några centrala utgångspunkter för den icke-konfessionella religionsvetenskapliga utbildningen och den kritik som har riktats mot dem.

\section{VÄRLDSRELIGIONSPARADIGMET OCH SEKULARISTISK DOXA}

Jag konstaterade precis att mindfulnessövningen illustrerar vad ett levd religion-perspektiv - till skillnad från representerad och rapporterad religion - kan innebära i utbildningen. Men den föreslagna vändningen inom icke-konfessionell religionsvetenskaplig utbildning som jag utreder här har också andra potentiella implikationer som rör ämnets konstitutiva element och dess doxa. Det rör å ena sidan det så kallade världsreligionsparadigmets dominans i religionsvetenskaplig utbildning, läromedelsproduktion och kursplaner, och å andra sidan grundläggande utgångspunkter som har omnämnts som sekulära eller till och med sekularistiska inom utbildningen.

Det kritiska begeppet världsreligionsparadigmet handlar kort sagt om grundläggande förutsättningar för den undervisning och forskning som bedrivs om religion. Det innebär att ramarna för att tala om religion inom utbildning präglas av specifika sätt att urskilja, sortera och jämföra olika religioner efter en bestämd ordning. Kritiken mot paradigmet innebär sammantaget att det reproducerar i grunden missvisande bilder av och uppfattningar om religion som i förlängningen riskerar att generera missuppfattningar och fördomar, i motsättning till vad som brukar omtalas som ett av religionsämnets syften. I Christopher R. Cotters och David G. Robertsons After World Religions (2016a), där ett flertal religionsvetare kritiserar världsreligionsparadigmet utifrån sin egen undervisningspraktik, adresseras den problematik som världsreligionsparadigmet är behäftat med. Carole M. Cusack summerar kritiken mot världsreligionsparadigmet på följande sätt: "[It] has been criticized as a simplified, Western-centric, and exclusionary model of religion that closes down interesting avenues of pedagogy and research" (Cusack, 2016, s. 164). Världsreligionsparadigmet är dessutom, menar Steven J. Sutcliffe, "a symptom of a wider chronic cognitive disease in which reified entities are represented in a hierarchy" (Sutcliffe, 20I6, s. 26). I en sådan hierarki befinner sig "the big five" - judendom, kristendom, islam, hinduism och buddhism - på toppen, medan folktro och nyandlighet på botten.

Världsreligionsparadigmet kritiseras även för att religiösa trosföreställningar och texter (urkunder) betonas i linje med den protestantiska kristendomens sola fide och sola scriptura. En sådan tendens har resulterat i en "'Christianizing' of 'other religions" menar Cotter och Robertson, som väcker frågan om "how different the Science of Religion might have been 
had it developed in contexts where non-Protestant traditions had been historically dominant" (Cotter \& Robertson, 2oI6b, s. 8). Därtill ifrågasätts världsreligionsparadigmets essentialistiska religionsförståelse. Religion tillskrivs en abstrakt och homogen essens, där ofta religionerna själva - snarare än de religiösa människorna - ges agens och handlingsförmåga. En sådan sui generis-förståelse av religion åsidosätter, menar kritikerna, religiositetens diversifierade, komplexa och kontextuella karaktär i historien och samtiden. ${ }^{2}$

Trädmetaforen, som jag menar är belysande för denna problematik, är en vanlig metafor när det gäller att tala om religionernas historia. ${ }^{3}$ I denna metafor utgör trädets stam den formativa perioden, medan rotsystemet - religionens förhistoria - är komplicerat och divergerat och därmed svårt att helt klarlägga. Av olika skäl utvecklas trädet till olika grenar, ofta med en klar markering i historien, som den mellan shiaislam och sunniislam, eller mellan öst- och västkyrkan, protestantismen och katolicismen. Dessa grenar får sedan ytterligare avknoppningar. Det innebär att historien blir mer komplicerad och mångfacetterad ju närmare vi kommer nutiden, och att den tidiga historien framstår som mer enhetlig och stabil. Den tidiga fasen - trädets stam framstår som den bas ur vilken grenar skjuter fram. Det innebär också att trädet är skiljt från andra träd, exempelvis hinduismträdet från kristendomsträdet. På så vis, menar jag, vilar även trädmetaforen i den så kallade boxmodellen som är vanligt förekommande i religionsvetenskapliga läromedel - där religionerna presenteras som mer eller mindre avgränsade entiteter - liksom i världsreligionsparadigmets essentialistiska religionsförståelse och en sui generis-förståelse av religion. ${ }^{4} \mathrm{Om}$ vi inte lyckas utföra religionsundervisningen utifrån andra utgångspunkter riskerar vi, utifrån detta resonemang, att representera religion på ett missvisande sätt som kan få till följd att fördomar och stereotyper reproduceras, snarare än motverkas, i utbildningen (se Horii, 2018; Fitzgerald, 2000; McCutcheon, I997; McCutcheon, 2003). Russinövningen är ett exempel på hur religionsundervisningen kan bedrivas utifrån andra utgångspunkter än de gängse, där ett levd religion-perspektiv, med dess fokus på materialitet och religiös praxis, innebär ett alternativ och komplement till representerad och rapporterad religion. Samtidigt är det viktigt att här understryka att även ett levd religion-perspektiv kan riskera att upprätthålla världsreligionsparadigmets essentialistiska religionsförståelse. Att exempelvis införa en kristen bön som religiös praktik i undervisningen innebär inte nödvändigtvis att en sui generis-förståelse av kristendom övervinns. Ett sådant inslag i undervisningen kan snarare bekräfta en sådan religionsförståelse. Ett levd religion-perspektiv kan emellertid förankra religion i praktik, materia och kroppar och därigenom påvisa religionens historicitet, variation och kontextbundenhet bortom världsreligionsparadigmets betoning av text och tro som abstrakta entiteter, och i förlängningen fungera som en utgångspunkt för att motverka essentialiserande inslag i religionsundervisningen. Jag återkommer strax till ett exempel på hur även religiösa texter kan användas - kroppsliggöras och praktiseras - inom ramen för undervisningen för att utveckla detta resonemang ytterligare.

2 För en diskussion om sui generis se McCutcheon (1997).

3 Trädmetaforen omnämns ibland som "familjeträd" och etablerar på så sätt en familjerelation mellan olika religioner.

4 Trädmetaforen väcker samtidigt en rad andra grundläggande frågor, som frågor om progression, evolution och linjär tidsuppfattning, liksom historieskrivning i relation till makt. Dessutom väcker trädmetaforen frågor som rör icke-akademisk teologi och religionsvetenskap; trädmetaforen används inte sällan, liksom uttrycket "Abrahams barn", teologiskt. Trädmetaforen förenas däremot numera sällan med ett mer uttalat evolutionärt perspektiv där religioners historia beskrivs i termer av en evolution från primitiva stadier till mer utvecklade, förfinade och rationella stadier. 
Trots att världsreligionsparadigmet har mött massiv kritik tycks det notoriskt svårt att göra sig av med i såväl läromedel som i religionsvetenskaplig utbildning. Inte ens om det utökas och skulle inkludera fler exempel på vad religion kan vara skulle det lösa den grundläggande problematiken som rör de försanttaganden, föreställningar och definitioner som präglar paradigmets religionsförståelse, utan snarare riskera att bekräfta underliggande antaganden om religion. Och trots den massiva kritik som har riktats mot världsreligionsparadigmet finns det flera pedagogiska poänger med paradigmet. Det förenklar, kort sagt, en komplicerad historia och komplexa fenomen så att de blir hanterbara inom ramen för en utbildning. Världreligionsparadigmet, där de fem (eller flera) världsreligionerna presenteras utifrån en essentialistisk boxmodell eller utifrån trädmetaforen, gör det svårbegripliga i bästa fall greppbart och begripligt. Problemet är inte heller primärt att utbildningen behandlar olika religioner, utan snarare de försanttaganden, föreställningar och maktordningar som reproduceras med världsreligionsparadigmet. Det jag hittills har argumenterat mot här, med avstamp i mindfulnessövningen, är tendensen att enbart presentera världsreligionerna som representerad och rapporterad religion. Frågan är därför nu i vilken utsträckning övningen också rymmer möjlighet att utmana själva världsreligionsparadigmet.

Övningen russinet i mindfulness för in "det religiösa" i religionsutbildningen genom materialitet (russinet) och praktik (det ledda ätandet och kroppsliggörandet av russinet), inte endast som ett exempel att kritiskt granska och analysera utan istället som en kroppsliggjord praktik att lära från. På så vis förs alltså den levda religionens praktik in som ett element i utbildningen. Michel Desjardins har argumenterat för att införa sådana praktiska element i religionsutbildningen som ett led i kritiken av världsreligionsparadigmet och som ett sätt att överkomma den problematik som paradigmet är en del av:

Focusing on food rather than ideology, on lived religion rather than textbook-constructed religion, allows students to appreciate, on their own, from their own data rather than from the classroom lectern, that religious food customs sometimes have more to do with ethnicity and immigration than they do with religion, and that some Muslims can have more in common with some Sikhs than they do with other Muslims. Letting the students discover this truth on their own makes it more likely that the knowledge will stick. (Desjardins, 20I6, s. 132)

Mindfulnessövningen kan alltså, i linje med Michel Desjardins resonemang, få kunskapen "att fastna" genom att den baseras i kroppsliga erfarenheter av autentiska matpraktiker i klassrummet som i sin tur vilar på tidigare erfarenheter av att äta russin, övningens enkelhet, samt sannolikt skillnaden mellan denna övning och andra undervisningspraktiker i religionsutbildning. En sådan övning kan därtill ge studenterna kunskap om att religion kan handla om a way of life, snarare än enbart föreskrivna dogmer och regler (Qvortrup Fibiger, 20I8, s. 8I). I linje med Desjardins argumentation kan praktiska element, som ätandet av ett russin, potentiellt sett även undergräva en sui generis-förståelse av religion, som framställer olika religioner som mer eller mindre slutna entiteter. På så vis kan sådana inslag i utbildningen undergräva centrala antaganden i världsreligionsparadigmet, som en text- och trosbaserad religionsförståelse, boxmodellen och trädmetaforen, som jag har redogjort för ovan.

Även om religiös praktik och religiösa föreställningar är centrala komponenter i religion, så ingår det vanligtvis inte i religionsutbildningen att studenter blir instruerade i hur religion kan praktiseras. Religiösa föreställningar och praktiker betraktas som regel som "data" som kan beskrivas och analyseras snarare än något forskare eller studenter ska engagera sig i för att få kunskap om religion, åtminstone inte inom ramen för en icke-konfessionell utbildning 


\section{Daniel Enstedt}

(se McCutcheon, 2006). Ett av antagandena i ett sådant synsätt är att man utgår från att den icke-konfessionella, till skillnad från den konfessionella, utbildningen är värdemässigt och religiöst neutral. Men är det verkligen så enkelt? I linje med sociologen Christian Smith och teologen John Milbank kan man istället argumentera för att den hegemoniska doxan i samhällsvetenskapliga och humanistiska utbildningar överlag inte bara är sekulär utan även sekularistisk (Milbank, I990; Smith, 20I4). En liknande sekularistisk doxa återfinns också i Karin Kittelmann Flensners studie av den icke-konfessionella religionsutbildningen i Sverige där en sekularistisk diskurs, som avfärdar religion som något daterat och förvetenskapligt, är påtaglig. I motsats till religion ställs det rationella och neutrala subjektet, och individualism och möjligheten att göra individuella val framstår som mer centrala värden i relation till olika aspekter av religion (Kittelmann Flensner, 20I5, s. 256). Sammantaget innebär detta att de sekulära normer och värderingar som utgör själva utgångspunkten för den icke-konfessionella, icke-religiösa och sekulära religionsutbildningen riskerar att avfärda religion som daterad, irrationell, ojämlik och förtryckande. Med andra ord kan man i linje med ett sådant resonemang konstatera att den sekulära och förment neutrala religionsutbildningen i själva verket kan vara sekularistisk och normativ. En sådan förskjutning pekar på en potentiell strukturell problematik inom religionsämnet som hör samman med en sekulär - eller alltså till och med sekularistisk - utgångspunkt för ämnet, liksom ett distanserande från ämnets konfessionella historia som kan resultera i ett avståndstagande från religiösa inslag $\mathrm{i}$ form av praktiker eller övningar i utbildningen som jag har föreslagit här. Resultaten från Karin Kittelmann Flensners studie är högintressanta för de resonemang som jag har fört här. Det skulle vara värdefullt att kunna fastställa i vilken utsträckning resultaten även speglar den religionsvetenskapliga utbildningen, men för att kunna säga något mer bestämt om detta behövs mer empirisk forskning.

\section{DEN BLOMSTERTID NU KOMMER}

Den tidigare föreslagna vändningen från ett ensidigt fokus på representerad och rapporterad religion till levd religion innebär naturligtvis inte att religiösa texter, föreställningar och berättelser ska lämnas därhän. Det handlar snarare om hur religiösa texter och trosföreställningar hanteras inom ramen för utbildningen.

En av de mest sjungna och välkända psalmerna är Den blomstertid nu kommer. För många människor som har genomgått den svenska skolan är psalmen bekant från skolavslutningar inför sommarlovet och sjungs antingen utomhus, i en kyrka eller skollokal. Psalmen sjungs vanligtvis inte $\mathrm{i}$ sin helhet och även om den har ett uppenbart religiöst och teologiskt innehåll förknippas den mest med den icke-konfessionella skolans avslutning. Sammantaget innebär detta att psalmen är välbekant för de flesta och utgör ett tacksamt underlag för religionskunskapsämnet. Jag har därför utarbetat ett undervisningsmaterial med anvisningar om hur denna psalm skulle kunna behandlas som jag i korthet ska återge här.

Studenterna får ta del av psalmtexten $\mathrm{i}$ sin helhet och initialt ställs frågan om vad psalmen handlar om. Det innebär att deras uppmärksamhet inledningsvis fokuseras på innehållsliga aspekter, vilket är ett vanligt förhållningssätt till texter. Vad handlar psalmen om? Studenterna delas in i tre grupper som får varsin mer specifik läsanvisning som lyder på följande sätt:

Grupp I läser texten konkret, bokstavligt. Formulera om texten del för del så att textens bokstavliga innebörd framträder i modernt språkbruk. Men undvik att tolka texten metaforiskt, allegoriskt, teologiskt eller etiskt! Beskriv så konkret som möjligt vad som sker och vem som gör vad i texten. 
Grupp 2 läser texten metaforiskt och allegoriskt. Vilka metaforer (bilder och liknelser) används i texten och vad betyder de? Vad är texten en allegori för? Vilken är textens egentliga mening? Vad uppmanar texten oss till?

Grupp 3 läser texten teologiskt. Vad betyder texten teologiskt? Vilken är textens teologi? Resonera kring relationerna mellan människa, natur och Gud, bibelanknytning och frågor som rör frälsning, skapelse och eskatologi (den yttersta tiden och döden).

Dessa läsanvisningar kan naturligtvis utökas med andra typer av läsningar, och samtidigt bör anvisningarna anpassas efter studentgruppen. I det ovanstående fallet är anvisningarna formulerade till religionslärarstudenter som läser på avancerad nivå. De har därmed en viss förförståelse när det gäller begrepp som teologi och eskatologi.

Psalmtexten och läsanvisningarna delas ut till studenterna utan att texten presenteras som psalm eller att kontexten ges. Grupperna får tid på sig att läsa texten enligt anvisningarna. När det är gjort gås läsningarna igenom i helklass, och begränsningar och möjligheter i de olika läsarterna dryftas. Om inte frågan har dykt upp kan läraren ställa den: vad är det som saknas i relation till textläsningen? Ett svar är naturligtvis den kyrkliga, rituella skolavslutningskontexten, med allt vad det innebär. Studenterna kan få en stund på sig att reflektera över allt som hör till den kontexten: byggnader, kläder, roller, ritualer, mat, lukter, emotioner, symboler, funktioner, tid, årstidscykler (kalenderritual), kroppar, ålder, religion, heligt/profant etc. Efter att dessa reflektioner har delgetts i helklass avslutas övningen genom att studenterna sjunger sången ståendes.

Målet med denna enkla övning är att påvisa vikten av att kontextualisera religiösa texter och uttryck för att närma sig en förståelse av det vi benämner religion. De religionslärarstudenter som gör övningen kan därtill reflektera över den i relation till undervisning om religion, gränserna för religiösa inslag i skolan och i undervisning samt de normer och värderingar som kringgärdar religionsundervisningen i grund- och gymnasieskolan. Följande är exempel på frågor som kan ställas. Vad är den pedagogiska poängen med att utgå från en psalm som brukar sjungas i en skolkontext och som de allra flesta har en relation till? Vad är poängen med att börja övningen med textläsning? Vad säger en sådan textuell utgångspunkt om religion, religionsförståelse och världsreligionsparadigmet? Vilken betydelse kan de rumsliga kontexterna - skolkontexten och kyrkobyggnaden - ha för praktiken? Man kan också ställa frågan om studenterna tidigare har reflekterat över vad de sjunger när de sjunger texten. Det är också möjligt att reflektera över övningen och materialval inom ramen för religionsutbildningen. Samtidigt möjliggör detta ett resonemang om den religiösa praktiken att sjunga och recitera texter inom olika religiösa traditioner.

Psalmens rituella, spatiala, materiella och tidsliga kontext och kroppsliga förankring genom sjungandet ger en tacksam inblick i att texter inte endast ska läsas analytiskt utan också inplaceras i ett vidare sammanhang, där minnen, erfarenheter, emotioner med mera också har betydelser för handlandet. Det är också tydligt att det här handlar om ortopraxi snarare är om ortodoxi. Det gemensamma handlandet genom sjungandet och kroppsliggörandet av Den blomstertid nu kommer hamnar i förgrunden, medan de tros- och textanalytiska inslagen som fokuserar på psalmens innehåll hamnar i periferin. Syftet med att genomföra det rituella handlandet att sjunga psalmen tillsammans med studenterna är alltså att förskjuta fokus från tro och text till handlande och ritual och därigenom fördjupa kunskapen om religion. Samtidigt syftar de olika läsarterna som föregår sjungandet till att påvisa att även läsandet är en form av handling, men som samtidigt skiljer sig från sjungandet. 


\section{ETISKA PERSPEKTIV PÅ RELIGIÖS PRAKTIK I ICKE-KONFESSIONELL UTBILDNING}

Slutligen vill jag diskutera några av de etiska frågor som kan väckas kring inslag av religiös praktik i högre utbildning. En fråga handlar om vilken övning som praktiseras. Det rör både övningens relevans, representativitet och lämplighet. Valet av övning bör, menar jag, läraren i vanlig ordning beakta i relation till utbildningens syfte och mål.

Religiösa praktiker som på olika sätt riskerar att psykiskt eller fysiskt skada, kränka eller utsätta studenter, eller andra, bör naturligtvis undvikas. Lärare inom högre utbildning kan föra ett resonemang kring detta med studenter och studenter kan involveras i valet av övningar liksom i utvärderingen av dem. Frågor om vem eller vilka som ska leda övningen och hur den ska genomföras kan också adresseras tillsammans med studenter som en del av utbildningen, inte minst i relation till frågor om hur ritualer utförs inom olika religiösa traditioner. Ytterligare en etisk aspekt som rör hur praktiken genomförs är kopplad till platsen - vad innebär det att genomföra en religiös praktik i en föreläsningssal snarare än i en församlingslokal? En annan möjlighet kan vara att, exempelvis i samband med ett studiebesök, delta i religiös praktik. Frågor som rör valet av praktik, hur den religiösa praktiken genomförs och platsen för genomförande kan alltså fungera som ett utmärkt underlag för vidare diskussion med studenter.

Ytterligare en etisk aspekt av att införa moment av religionsutövande i undervisningen rör studenters deltagande. Det är svårt att föreställa sig att sådana inslag i utbildningen kan göras tvingande och kopplas till examinationen, utan bör snarare ske på frivillig basis. Det är sannolikt att någon eller några studenter inte kommer att delta i samtliga övningar. Det innebär dock inte att lärare helt behöver avstå från att föra in religiös praktik i utbildningen i linje med hur jag har resonerat ovan. Religiösa praktiker i undervisningen kan också riskera att peka ut dem som eventuellt inte väljer att delta, exempelvis för att det strider mot deras egen religiositet eller frånvaro av religiositet på ett sätt som riskerar inkräkta på deras integritet. Detta är en etisk problematik som lärare har att hantera även i andra situationer, och som bör hanteras i relation till den kurs och den studentgrupp det gäller. Det handlar om bedömningar som lärare kan behöva göra själva, eller tillsammans med lärarkollegiet och studenter.

Liknande frågor kan naturligtvis också väckas i relation till skolämnen på lägre nivåer, som ämnena hem- och konsumentkunskap eller idrott och hälsa, samt i relation till aktiviteter som alltjämt försiggår i många skolor runt om i landet, som att sjunga psalmen Den blomstertid nu kommer vid skolavslutningar eller att utöva mindfulness som avslappning i skolmiljön. I gymnasieämnet Hälsa, för att ge ett exempel, ska eleverna "ges möjlighet att utveckla insikt om den egna livsstilen och förmåga att utföra handlingar för ett ökat välbefinnande och en positiv självbild" (Skolverket, 20Io). En del av kursens centrala innehåll är "Mentala avslappnings- och träningsmetoder, till exempel mindfulness" (Skolverket, 20Io). Psalmsjungande och mindfulnessövningar tycks alltså inte vara särskilt problematiska i en skolmiljö. Frågan är när russinet $i$ mindfulness och Den blomstertid nu kommer blir problematiska inslag i ett icke-konfessionellt utbildningssammanhang. De flesta är förmodligen eniga om att det är möjligt att läsa psalmen och instruktionerna till mindfulnessövningen (rapporterad religion), liksom att ta del av andra människors praktik - sjungande och ätande - genom video eller studiebesök (representerad religion). Är det när undervisningen övergår till praktik, när studenten sjunger psalmen högt eller äter russinet, som etiska problem uppstår? Eller är det etiketteringen, att omnämna övningarna som religiösa eller andliga inom ramen för religionsvetenskaplig utbildning? De övningar som jag har resonerat kring här rör sig i ett konceptuellt gränsland och kan fungera utmärkt 
för att resonera kring definitionsfrågor och vad definitioner av andlighet och religion gör med förståelsen av praktiken.

Frågan är om inte eventuella invändningar mot att införa praktiska element i själva verket handlar om en djupare och mer grundläggande problematik i synen på religionsämnet. Om det är så att umgänget med religiösa texter, tankar och föreställningar framstår som oproblematiskt när det gäller representerad och rapporterad religion så bör varje religionsvetare väcka frågor om vad ett sådant ställningstagande gör med kunskapen om religion och vilka utgångspunkter sådana antaganden vilar på, liksom vad det är för potentiell kunskap som diskvalificeras i en sådan ordning.

\section{ERFARENHETSBASERAD UTBILDNING OCH PRAKTIK I RELIGIONSVETENSKAP}

Ett övergripande syfte med denna artikel har varit att urskilja och problematisera ett rådande paradigm inom religionsvetenskaplig utbildning och prova argumenten för ett kompletterande förhållningssätt. Det som har intresserat mig här är i första hand frågan om ett slags pedagogiskt engagemang med religion i den icke-konfessionella religionsutbildningen (jfr Spickard, Landres \& McGuire, 2002). Att lära genom praktik handlar här inte i första hand om generiska kompetenser, som exempelvis vetenskapliga metoder och analyser, eller akademiskt skrivande. I de fallen är förmodligen de flesta, även inom religionsämnet, överens om att det behövs färdighetsträning för att nå kunskap. Det handlar istället om kunskap om religion där en gräns ofta dras mellan den icke-konfessionella religionsutbildningen och färdighetsträning i form av religiös praktik eller religiösa inslag i utbildningen. Genom att föra in levd religion, materialitet och religiösa praktiker i den icke-konfessionella utbildningen kompletterar vi lära genom åskådning, analys och tänkande, med lära genom görande.

Det jag föreslår här är alltså att religiös praktik beaktas och förs in - på det sätt och i de fall läraren bedömer lämpligt $i$ såväl relation till syftet med utbildningen som utifrån etiska överväganden - i den icke-konfessionella religionsvetenskapliga utbildningen i Sverige. Utan en fördjupad religiös litteracitet med förankring i religiös praktik riskerar, kort sagt, religion att bortförklaras snarare än förklaras; de religiösa uttrycken missförstås snarare än förstås. En sådan risk är intimt förknippad med en potentiell förskjutning av gränsen mellan icke-konfessionell utbildning och en sekularistisk bias. En icke-konfessionell utbildning innebär inte att enbart representerad eller rapporterad religion behandlas; övningar och inslag som innefattar religiös praktik kan rymmas i utbildningen utan att utbildningen för den sakens skull blir konfessionell. Jag har här gett två exempel som med enkelhet kan mångfaldigas.

\section{FÖRFATTARPRESENTATION}

Daniel Enstedt är docent i religionsvetenskap med inriktning mot religionsbeteendevetenskap. Han är verksam vid Göteborgs universitet och har genomfört flera fältstudiebaserade projekt om bland annat avhopp från islam, sexualitet och kristen tro, andlighet och religiositet inom den palliativa vården samt nya religiösa praktiker i Norden. Därtill har han under en längre tid, först som studierektor och sedan som viceprefekt för utbildning, arbetat med pedagogiskt utvecklingsarbete i religionsvetenskap, litteraturvetenskap och idéhistoria.

\section{REFERENSER}

Airasian, P. W., Anderson, L. W., Krathwohl, D. R. \& Bloom, B. S. (2001). A Taxonomy for Learning, Teaching, and Assessing: A Revision of Bloom's Taxonomy of Educational Objectives. New York: Longman. 


\section{Daniel Enstedt}

Ammerman, N. T. (red.) (2007). Everyday Religion: Observing Modern Religious Lives. New York: Oxford University Press.

Ammerman, N. T. (2014). Sacred Stories, Spiritual Tribes: Finding Religion in Everyday Life. Oxford: Oxford University Press.

Biesta, G. (2014). The Beautiful Risk of Education. Boulder: Paradigm Publishers.

Biggs, J. B. \& Tang, C. S. (1999). Teaching for Quality Learning at University: What the Student does. 3rd ed. Maidenhead: McGraw-Hill/Society for Research into Higher Education \& Open University Press.

Burke, K. (2009). How to Assess Authentic Learning. Thousand Oaks, Calif.: Corwin Press.

Cotter, C. R. \& Robertson, D. G. (2016a). After World Religions: Reconstructing Religious Studies. Abingdon: Routledge.

Cotter, C. R. \& Robertson, D. G. (2016b). Introduction. I C. R. Cotter \& D. G. Robertson (red.), After World Religions: Reconstructing Religious Studies, s. 1-20. Abingdon: Routledge.

Cusack, C. M. (2016). Archeology and the World Religions Paradigm: The European Neolithic, Religion and Cultural Imperialism. I C. R. Cotter \& D. G. Robertson (red.), After World Religions: Reconstructing Religious Studies, s. 153-167. Abingdon: Routledge.

Desjardins, M. (2016). The Desjardins Diet for World Religions Paradigm Loss. I C. R. Cotter \& D. G. Robertson (red.), After World Religions: Reconstructing Religious Studies, s. 123-137. Abingdon: Routledge.

Enstedt, D. (2014). Enneagramreceptionen i Sverige. I Chaos: Skandinavisk tidsskrift for religionshistoriske studier. 62 (2), s. 115-148.

Enstedt, D. (2020). (Re)thinking Religious Studies. I Educational theory [kommande]

Enstedt, D. \& Plank, P. (red.) (2018). Levd religion: Det heliga i vardagen. Lund: Nordic Academic Press.

Fitzgerald, T. (2000). The Ideology of Religious Studies. New York: Oxford University Press.

Gregg, S. E. \& Scholefield, L. (2015). Engaging with Living Religion: A Guide to Fieldwork in the Study of Religion. Abingdon: Routledge

Hedin, A. (2006). Lärande på hög nivå: idéer från studenter, lärare och pedagogisk forskning som stöd för utveckling av universitetsundervisning. Uppsala: Avdelningen för utveckling av pedagogik och interaktivt lärande (UPI), Uppsala universitet

Hedstrom, M. S. (2018). Buddhist Fulfillment of a Protestant Dream: Mindfulness as Scientific Spirituality. I W. B. Parsons (red.), Being Spiritual but Not Religious: Past, Present, Future(s), s. 57-71. Abingdon, Oxon: Routledge.

Herrington, T. \& Herrington, J. (red.) (2005). Authentic Learning Environments in Higher Education. Hershey, PA: Information Science Pub.

Herrington, J., Reeves, T. C. \& Oliver, R. (2014). Authentic Learning Environments. I eds. J. M. Spector, D. M. Merrill, J. Elen, \& M. J. Bishop (red.), Handbook of Research on Educational Communications and Technology, s. 401-412. New York, NY: Springer.

Horii, M. (2018). The Category of 'Religion' in Contemporary Japan: Shükyō and Temple Buddhism. New York: Palgrave Macmillan.

Houtman, D. \& Meyer, B. (red.) (2012). Things: Religion and the Question of Materiality. New York: Fordham University Press.

Kittelmann Flensner, K. (2015). Religious Education in Contemporary Pluralistic Sweden. Göteborg: University of Gothenburg.

McCutcheon, R. T. (1997). Manufacturing Religion: The Discourse on Sui Generis Religion and the Politics of Nostalgia. New York: Oxford University Press.

McCutcheon, R. T. (2003). The Discipline of Religion: Structure, Meaning, Rhetoric. London: Routledge.

McCutcheon, R. T. (2006). 'It's a Lie. There's No Truth in It! It's a Sin!': On the Limits of the Humanistic Study of Religion and the Costs of Saving Others from Themselves. I Journal of the American Academy of Religion. 74 (3), s. 720-50.

McGuire, M. B. (2007). Lived Religion: Faith and Practice in Everyday Life. New York: Oxford University Press. 
Milbank, J. (1990). Theology and Social Theory: Beyond Secular Reason. Oxford: Blackwell.

Moore, D. L. (2007). Overcoming Religious Illiteracy: A Cultural Studies Approach to the Study of Religion in Secondary Education. New York: Palgrave Macmillan.

Pettersen, R. C. (2008). Kvalitetslärande i högre utbildning: Introduktion till problem- och praktikbaserad didaktik. Stockholm: Studentlitteratur

Plank, K. (2011). Insiktoch närvaro: Akademiska kontemplationerkringbuddhism, meditation och mindfulness. Diss. Lund: Lunds universitet.

Plank, K. (red.) (2014). Mindfulness: Tradition, tolkning och tillämpning. Lund: Nordic Academic Press.

Qvortrup Fibiger, M. (2018). Hinduiska processioner i Mauritius. I D. Enstedt \& K. Plank (red.), Levd Religion: Det heliga i vardagen, s. 81-98. Lund: Nordic Academic Press.

Sandberg,J. (2015). Öva mindfulness - med hjälp av ett russin! I Må bra http://mabra.com/ova-mindfulnessmed-hjalp-av-ett-russin/ (läst 2019-12-16).

Skolverket (2010). "Hälsa" https://www.skolverket.se/sitevision/proxy/undervisning/gymnasieskolan/ laroplan-program-och-amnen-i-gymnasieskolan/gymnasieprogrammen/amne/svid12_5dfee44715 d35a5cdfa92a3/1530314731/syllabuscw/jsp/subject/HAL/2/pdf

Smith, C. (2014). The Sacred Project of American Sociology. New York: Oxford University Press.

Spickard, J. V., Landres, J. S. and McGuire, M. B. (red.) (2002). Personal Knowledge and Beyond: Reshaping the Ethnography of Religion. New York: New York University Press

Sutcliffe, S. (2016). The Problem of 'Religions': Teaching Against the Grain with 'New Age Stuff. I C. R. Cotter \& D. G. Robertson (red.) After World Religions: Reconstructing Religious Studies. Abingdon: Routledge.

Walvoord, B. E. F. (2008). Teaching and Learning in College Introductory Religion Courses. Oxford: Blackwell. 